УДК $621.798(620.2): 658.788 .4$

О.Ю. РЕЧУН, О.І. ПЕРЕДРІЙ

Луцький національний технічний університет

\title{
АКТИВНЕ ТА РОЗУМНЕ ПАКОВАННЯ ХАРЧОВИХ ПРОДУКТІВ
}

\author{
O. RECHUN, O. PEREDRIY
}

Lutsk national technical university

\section{ACTIVE AND REASONABLE FOOD PACKAGING}

\section{https://doi.org/10.36910/6775-2310-5283-2021-14-7}

\begin{abstract}
Мета. Метою статті є розгляд основних видів активного та розумного паковання харчових продуктів, аналіз їх переваг і недоліків, зокрема, їх випливу на якість і безпечність продуктів та інформативність упаковки, огляд ключових технологій, які можуть бути використані в активних і розумних системах, а також аналіз існуючого законодавства, щуо регулює використання активного та розумного паковання, та визначення основних перешкод на шляху поширення використання інноваційних видів паковання в Украӥні.
\end{abstract}

Методика. Використано методи теоретичного пошуку, системного підходу та логічного узагальнення.

Результати. У статті подано класифікацію активного і розумного паковання, а також коротко розглянуто основні технологї, щуо використовують у розумних $i$ активних системах. Наведено приклади активного та розумного паковання для різних видів харчових продуктів,обтрунтовано переваги його використання для продуктів харчування. Розглянуто проблему безпечності активного та розумного паковання та регулювання його використання на прикладі законодавства ЄС, США та України. Визначено перешкоди на шляху поширення інноваційних технологій пакування в Украӥні та світі, а також перспективи їх подальшого розвитку.

Наукова новизна. На съогодні активне та розумне паковання майже не доступне для украйнського споживача. Досі не було повністю розглянуто та структуровано перешкоди та перспективи розвитку ичих видів паковання в умовах Украӥни.

Практична значимість. Суспільство постійно розвивається, а інноваційне паковання є результатом попиту споживачів на упаковку, яка є більш досконалою та креативною. Активне та розумне паковання - ие результат інноваційного мислення в упаковці. Воно здатне покращити якість $і$ безпечність харчових продуктів, а також повідомити споживачу актуальну інформацію про стан продукту, щуо змінюється в часі. Поширення нових технологій паковання є необхідним етапом розвитку торгівлі, щуо здатен задовольнити дедалі складніші вимоги споживача, зменшити кількість харчових відходів $i$ зробити паковання якіснішим, безпечнішим і зручнішим. 
Ключові слова: технологї̈ паковання, активне паковання, розумне паковання, харчові продукти, якість, безпечність.

\section{Постановка проблеми у загальному вигляді і її зв'язок з важливими} науковими та практичними завданнями. Традиційна роль упаковки харчових продуктів продовжує розвиватися у відповідь на мінливі потреби ринку. Рушійними силами цих змін $є$ попит споживачів на безпечніші, «здоровші» та якісніші продукти, що мають тривалий термін зберігання. Ці фактори призвели до розвитку нових технологій пакування, появи нових форм паковання, а саме: активного та розумного паковання. Роль різних видів смартпаковання у зростанні якості продуктів особливо помітна на прикладі паковання продуктів харчування. Якісні характеристики цих товарів швидко змінюються в процесі товарообігу, тому постійний контроль за їх збереженістю $\epsilon$ дуже важливим, не лише у процесі виробництва, а й на стадії реалізації. Забезпечують такий контроль розумні системи паковання, які сприяють подовженню терміну зберігання продуктів, покращенню якості та товарного вигляду. Однак на сьогодні українські споживачі не можуть повною мірою скористатися усіма перевагами нових видів паковання. 3 метою поширення цих видів паковання в Україні необхідно краще ознайомити споживачів i виробників харчової продукції 3 технологіями активного та розумного пакування, а також розробити чітку систему державного контролю за якістю та безпечністю цих видів упаковки.

Цілі статті. Метою статті $є$ аналіз основних видів активного та розумного паковання харчових продуктів, визначення їх переваги та недоліки, а також визначення основних перешкоди їх використання в Україні.

Виклад основного матеріалу. Протягом останніх років у закордонній літературі з'являються численні публікації щодо перспектив використання активного та розумного паковання, зокрема, для харчових продуктів [1,2]. Науковці та виробники активно досліджують технології та матеріали, що використовують у смарт-пакованні, задля створення ефективних і безпечних розумних [3] та активних систем [4]. У відповідь на попит серед споживачів зростає необхідність створення натуральних високоякісних харчових продуктів, які не обробляються або обробляються мінімально, не містять консервантів, але мають прийнятний термін зберігання [4]. Тому захисна функція упаковки повинна бути вдосконалена, що призвело до розробки нових технологій упаковки, таких як упаковка із модифікованою атмосферою [5]. Перспективним 
напрямком також є використання наночастинок у якості компонентів активного паковання [6,7]. Однак окрім створення новітніх технологій пакування необхідно також подолати труднощі, пов'язанні 3 регулюванням їх використання та впровадженням на практиці. Варто зазначити, що ці питання були успішно вирішені в межах Свропейського союзу [8]. Напротивагу в українській літературі знаходимо значно менше публікацій за даною тематикою. Окремі автори, О.М. Гавва, С.В. Токарчук, О.О. Кохан, С.Ф. Гавенко, О.М. Савченко, вже звертали увагу на переваги активного та розумного паковання. Проте дані публікації нечисленні, недостатньо проаналізоване використання активного та розумного паковання, не виявлено основні перешкоди його впровадження та шляхи їх подолання.

Активним пакованням називають упаковку, в якій допоміжні складові були навмисно включені в пакувальний матеріал або нанесені на пакувальний матеріал чи зовні упаковки для підвищення ефективності системи упаковки. Це визначення наголошує на важливості навмисного включення речовини 3 метою покращення харчового продукту. Активне паковання має на меті покращення захисної функції упаковки i, зазвичай, використовується для захисту від кисню та вологи.

Активне паковання реалізується найчастіше у вигляді саше або ж матеріал самої упаковки містить активні системи чи компоненти. За основними функціями активне паковання можна поділити на наступні групи: абсорбери або очищувачі (системи, які або поглинають небажану речовину, або перетворюють іiі в іншу більш інертну сполуку), вивільнювачі або емітери, антимікробні та антибактеріальні системи, системи контролю за температурою.

Активна упаковка - це інноваційний підхід до збереження або подовження терміну придатності харчових продуктів, який одночасно забезпечує їх якість, безпечність та цілісність. Як визначено в Регламенті (ЄС) №450/2009, активна упаковка включає пакувальні системи, які взаємодіють 3 харчовими продуктами, оскільки, «містять свідомо додані компоненти, які вивільняють або поглинають речовини в упаковані харчові продукти або у середовище, що їх оточує». Активні системи упаковки можна розділити на активні системи видалення (абсорбери) та системи активного вивільнення (емітери). У той час як перші видаляють небажані сполуки 3 їжі або середовища, яке їі оточує, наприклад, вологу, вуглекислий газ, кисень, етилен або неприємний запах, другі виділяють сполуки в упаковану їжу або у середовище упаковки, такі як антимікробні сполуки, діоксид вуглецю, 
антиоксиданти, ароматизатори, етилен або етанол. У таблиці 1 наведено огляд основних технологій активної упаковки та потенційних переваг їх додавання до упаковки харчових продуктів.

\section{Таблиця 1. Приклади активного паковання харчових продуктів}

\begin{tabular}{|c|c|c|}
\hline $\begin{array}{c}\text { Тип активного } \\
\text { паковання }\end{array}$ & Тип харчового продукту & Потенційна вигода \\
\hline \multicolumn{3}{|c|}{ Активні системи видалення (абсорбери) } \\
\hline \multirow[t]{4}{*}{$\begin{array}{l}\text { Поглиначі } \\
\text { кисню }\end{array}$} & Готові м’ясні продукти & Запобігання зміні кольору \\
\hline & $\begin{array}{c}\text { Тертий сир, попередньо } \\
\text { приготовані хлібобулочні вироби }\end{array}$ & Запобігання появи цвілі \\
\hline & Фруктові та овочеві соки & $\begin{array}{c}\text { Зберігання вмісту вітаміну C, } \\
\text { запобігання побурінню }\end{array}$ \\
\hline & $\begin{array}{c}\text { Насіння, горіхи та олії; порошки } \\
\text { швидкого приготування, що } \\
\text { містять жир, смажені перекуси; } \\
\text { сушені м’ясні продукти }\end{array}$ & Запобігання появи гіркоти \\
\hline $\begin{array}{l}\text { Поглиначі } \\
\text { вологи }\end{array}$ & $\begin{array}{c}\text { Гриби, помідори, полуниця, } \\
\text { кукурудза, зерно, насіння, свіжа } \\
\text { риба та м’ясо }\end{array}$ & $\begin{array}{c}\text { Подовження терміну придатності за } \\
\text { рахунок підтримання сталого вмісту } \\
\text { вологи, зменшення конденсації } \\
\text { вологи в упаковці, позитивний вплив } \\
\text { на зовнішній вигляд, зменшення } \\
\text { побуріння або зміни кольору }\end{array}$ \\
\hline $\begin{array}{l}\text { Поглиначі } \\
\text { етилену }\end{array}$ & Клімактеричні фрукти та овочі & $\begin{array}{c}\text { 3меншення інтенсивності дозрівання } \\
\text { та старіння, підвищення якості та } \\
\text { подовження терміну зберігання }\end{array}$ \\
\hline \multicolumn{3}{|c|}{ Активні системи вивільнення (емітери) } \\
\hline $\begin{array}{l}\text { Вивільнювачі } \\
\text { антиоксидантів }\end{array}$ & $\begin{array}{c}\text { Свіжа жирна риба та м’ясо; } \\
\text { порошки для швидкого } \\
\text { приготування, що містять жири; } \\
\text { насіння, горіхи та олії; смажені } \\
\text { продукти } \\
\end{array}$ & Покращення стійкості до окиснення \\
\hline $\begin{array}{l}\text { Емітери карбон } \\
\text { діоксиду }\end{array}$ & Свіжа риба та м'ясо & $\begin{array}{c}\text { Подовження мікробіологічного } \\
\text { терміну зберігання, зменшення } \\
\text { вільного об'єму упаковки } \\
\end{array}$ \\
\hline $\begin{array}{l}\text { Антимікробні } \\
\text { системи }\end{array}$ & $\begin{array}{c}\text { Свіже та приготоване м’ясо, } \\
\text { свіжа та копчена риба, свіжі } \\
\text { морепродукти, молочні продукти, } \\
\text { свіжі та приготовані фрукти та } \\
\text { овочі, зерно, крупи та } \\
\text { хлібобулочні вироби, страви, } \\
\text { готові до вживання }\end{array}$ & $\begin{array}{c}\text { Пригнічення або уповільнення } \\
\text { розмноження бактерій, подовження } \\
\text { терміну зберігання }\end{array}$ \\
\hline
\end{tabular}

Розглянемо детальніше найпоширеніші види активного паковання. Серед поглиначів найчастіше використовують системи, які зменшують вміст кисню, вологи, етилену або карбон діоксиду в упаковці. 
Застосування поглиначів кисню є однією з основних активних технологій упаковки, яка спрямована на видалення залишків кисню, що містяться в упаковці продуктів, або покращення іiі бар'єрних властивостей. Кисень в упаковці негативно впливає на якість та термін зберігання багатьох продуктів, оскільки призводить до окислення продукту або сприяє розвитку аеробних мікроорганізмів. Механізм поглинання кисню, в основному, хімічний. Найбільш поширеними є поглиначі на основі заліза, за наявності вологи відбувається процес необоротного окиснення відновленого заліза до стабільного тригідрату оксиду заліза. Швидкість окислення заліза можна додатково збільшити, використовуючи наночастинки заліза, змішані 3 активованим вугіллям, хлоридом натрію та хлоридом кальцію.

Широкого використання також набувають абсорбери вологи, які зменшують вміст вологи в упаковці. Високий вміст води в упаковці може бути викликаний різними факторами, наприклад, захоплення вологи в процесі пакування, виділення через коливання температури, дихання свіжих продуктів, низька паропроникність упаковки тощо. Надлишок води зменшує термін зберігання їжі, оскільки сприяє розмноженню мікробів, спричиняючи небажані зміни якості їжі, особливо у сухих продуктах. Крім того, наявність рідини всередині упаковки сирої риби та м'яса через витікання, утворення конденсату в упаковці свіжих фруктів та овочів призводить до зменшення привабливості продукту для споживачів. Прикладами комерційно доступних поглиначів вологи $є$ абсорбуючі подушечки, аркуші, лотки та обгортки. За структурою вони складаються 3 двох шарів мікропористої нетканої плівки з поліетилену, поліпропілену тощо, що містить активну речовину, таку як суперабсорбуючий полімер, адсорбенти на основі силікагелю, хлорид натрію, кополімери крохмалю тощо.

Наявність діоксиду карбону в упаковці може мати як позитивний, так i негативний ефект. Як один 3 основних продуктів катаболічних реакцій організмів, він може виділятися в процесі метаболізму самого продукту або мікроорганізмів. Для усунення надлишку вуглекислого газу зазвичай використовують саше, що містять оксид кальцію, який за наявності вологи утворює з карбон діоксидом кальцій карбонат.

Розвиток мікроорганізмів всередині упаковки є однією з основних причин псування харчових продуктів. Антимікробна упаковка може бути ефективним інструментом для вирішення цієї проблеми. Активні емітери, що містяться в упаковці, мають на меті забезпечити контрольоване вивільнення сполук, здатне 
забезпечити оптимальний рівень вологості, інгібування розвитку шкідливих мікроорганізмів та запобігання псуванню харчових продуктів під дією бактерій. Ефективним антимікробним агентом може служити карбон діокисид. Для отримання карбон діоксиду використовують системи, що містять ферум (II) карбонат, комбінації бікарбонату натрію та лимонної кислоти тощо. На практиці зазвичай використовуються саше або подушечки 3 подвійною дією емітерів $\mathrm{CO}_{2}$ та поглиначів $\mathrm{O}_{2}$. В якості антимікробного агента також використовують етанол, який особливо ефективно пригнічує розвиток дріжджів i бактерій, що, зокрема, значно подовжує термін зберігання хлібобулочних виробів. Вивільнювачі етанолу застосовують у вигляді саше або плівок, що можуть також містити ароматизатори для маскування спиртового запаху.

Розумним пакованням називають упаковку, яка містить зовнішній або внутрішній індикатор для надання інформації про аспекти історії упаковки та / або якості їжі. Розумне паковання забезпечує розширення комунікаційної функції традиційної упаковки, оскільки, воно передає споживачеві інформацію, яка базується на його здатності відчувати, виявляти або фіксувати зовнішні чи внутрішні зміни в середовищі товару.

Існує три основних типи систем, які використовують у розумному пакованні, які включають датчики, індикатори та штрих-коди та пристрої для радіочастотної ідентифікації (RFID). Види розумного пакування узагальнені на рис.1. Розглянемо основні види розумного паковання. Датчик - це прилад, який використовують для виявлення, пошуку або кількісної оцінки певного фактора та передачі сигналів для вимірювання його фізичних або хімічних характеристик. Зазвичай датчики складаються з рецептора і перетворювача. Функція рецептора полягає у перетворенні фізичної або хімічної інформації у форму енергії, а перетворювач змінює енергію на аналітичний сигнал.

Для забезпечення якості та безпеки харчових продуктів важливою $\epsilon$ розробка розумних систем упаковки харчових продуктів, що використовують портативні хімічні датчики для контролю наявності певних хімічних сполук, зокрема, $\mathrm{H}_{2}, \mathrm{O}_{2}, \mathrm{NO}_{2}$ та $\mathrm{CO}_{2}$ в упаковках із модифікованою атмосферою.

Індикатори використовують для надання інформації щодо будь-яких змін, що відбуваються в харчовому продукті або середовищі навколо нього (наприклад, температура, $\mathrm{pH}$ тощо), спостерігаючи за візуальними змінами, як правило, у кольорі. Особливістю індикаторів є те, що вони не мають рецепторів або перетворювачів, як датчики, натомість вони надають інформацію лише за допомогою прямих візуальних змін. Індикаторами, що застосовуються для 
упаковки харчових продуктів, є індикатори часу та температури, концентрації газу та свіжості

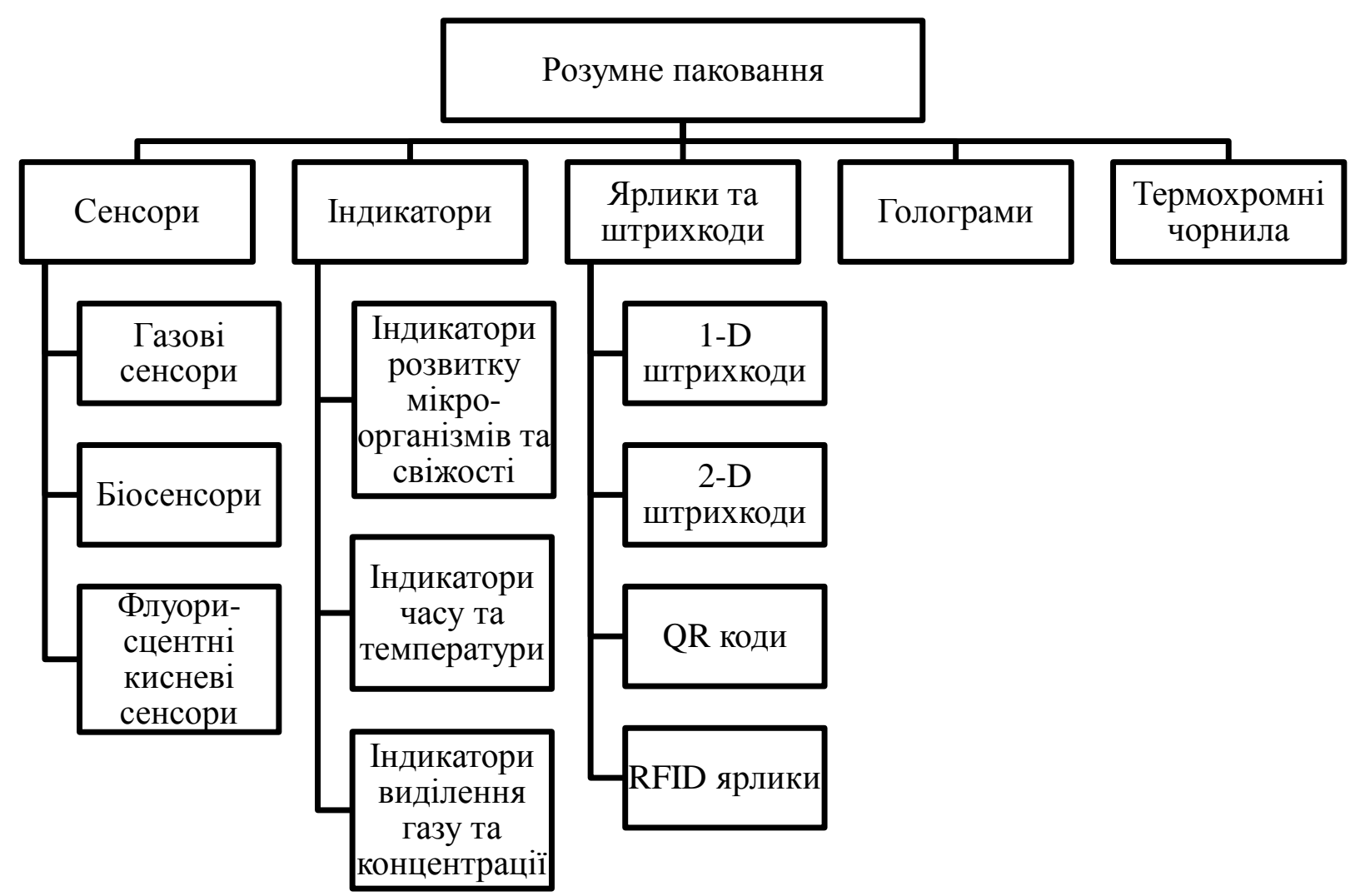

\section{Рис. 1. Класифікація розумного паковання}

Індикатори часу i температури використовуються для перевірки температури продукту та середовища упаковки, а також інформування споживачів про наявність розвитку мікроорганізмів та структурних змін продукту. Індикатори свіжості інформують про якість продуктів харчування 3 точки зору мікробного росту або хімічних змін, що відбулися в харчових продуктах. Газові індикатори використовують у вигляді етикеток для перевірки концентрації газу всередині упаковки.

Штрих-коди та RFID ярлики - це переважно носії даних. Штрих-код широко використовується для прискорення товарообігу, впорядкування товарів та перевірки цін. Повідомлення декодується та інтерпретується оптичним сканером штрих-коду, який передає необхідне повідомлення в систему, де воно зберігається для подальших необхідних дій. Ярлики RFID, в основному, складаються з трьох компонентів: мітки, виготовленої з мікрочіпу, сполученого 3 невеликою антеною, зчитувача, здатного надсилати радіосигнали, а також 
приймати відповіді від мітки у відповідь на надіслані сигнали, та пов'язаної мережевої системи або веб-сервера. Найдосконаліші системи RFID здатні приймати дані з відстані 100 м, при діапазоні зберігання 1 Мб. На сьогодні система RFID складається 3 двох типів ярликів: активних та пасивних. Використання акумулятора в активних ярликах відрізняє їх від пасивних.

Окрім вищезазначених систем, голограми та термохромні чорнила також $\epsilon$ корисними інструментами, які можна використовувати в пакованні харчових продуктів. Голограма допомагає захистити торгову марку товару, а також боротися 3 фальсифікацією. На сьогодні голограми, в основному, використовують у фармацевтичній промисловості, а їх застосування у секторі паковання харчових продуктів дуже обмежене. 3 розвитком технологій розумних систем упаковки очікується, що найближчим часом будуть доступні голограми для харчових продуктів. Термохромні чорнила найчастіше використовують для упаковки напоїв або харчових продуктів для мікрохвильовки, що надає споживачам інформацію про температуру продукту та його готовність для подачі.

Використання активного та розумного паковання забезпечує вигоду як для виробників i реалізаторів харчової продукції, так i для споживачів. Перевагою активного паковання з точки зору споживача $\epsilon$ покращення якості продукту, його товарного вигляду, а подовження терміну зберігання становить глобальну вигоду, оскільки, призводить до зменшення кількості харчових відходів. Системи розумного паковання дозволяють споживачеві отримувати актуальну та зрозумілу інформацію про стан продукту, дозволяють виявити порушення умов зберігання, а також зменшити кількість підробок.

Окрім очевидних переваг використання активного та розумного паковання викликає певні дискусії та створює ряд перешкод при впровадженні на практиці. Постає питання регулювання використання активного та розумного паковання, що особливо важливо з погляду на те, що зазвичай воно перебуває у прямому контакті з їжею, а отже, компоненти паковання можуть переходити у харчові продукти та спричиняти небажаний вплив на здоров'я споживача.

У Свропі активне та розумне паковання повинне узгоджуватися iз законодавством щодо матеріалів, які контактують 3 харчовими продуктами, що включає оцінку загальних меж міграції (OML), специфічних меж міграції (SML) та токсикологічних властивостей. Зокрема, Регламент 1935/2004/СC [9] встановлює у ст. 3, що будь-який матеріал або виріб, призначений для прямого 
чи опосередкованого контакту 3 продуктами харчування, повинен бути виготовлений з дотриманням належної виробничої практики таким чином, щоб у звичних i передбачуваних умовах їх складові не мігрували до продуктів харчування в кількості, яка може представляти ризик для здоров'я людини, змінити склад їжі або погіршити органолептичні властивості їжі. Крім того, Регламент 1935/2004/СС у статті 4 регулює маркування, яке повинно вказувати на те, що деталі не $є$ їстівними, а розумні матеріали не повинні надавати інформацію про стан харчових продуктів, що може ввести споживачів в оману [9]. Регламент Комісії 450/2009/СС [10] стосується лише активних та розумних матеріалів та виробів, призначених для контакту 3 продуктами харчування. Зокрема, у ньому підкреслюється, що розумні паковальні системи не повинні виділяти свої компоненти в їжу. Крім того, діюча речовина, яка навмисно виділяється в їжу або має технічний ефект, повинна відповідати Регламенту 1333/2008/СС [11], що стосується прямих харчових добавок. Для вже затверджених речовин, які входять до складу активних матеріалів за допомогою таких методів, як прищеплення та іммобілізація, виробник повинен виконати оцінку безпеки та перевірити стабільність речовин в разі проходження хімічної реакції, деградації або розкладання. Крім того, активні речовини не повинні вводити споживача в оману (наприклад, маскуючи зіпсовану їжу), i вони повинні бути вказані на етикетці, яка містить напис «не їсти» або символ, щоб запобігти помилковому попаданню в їжу непридатної частини.

У США, навпаки, активне та розумне паковання розглядають в рамках існуючої системи згідно з Кодексом федеральних правил, і жодних конкретних положень не розроблено. Матеріали, що використовують в продуктах, які контактують 3 харчовими продуктами, підлягають попередньому дозволу 3 боку Адміністрації США з питань харчових продуктів і медикаментів, якщо вони вважаються «харчовими добавками» відповідно до Федерального закону про харчові продукти, ліки та косметику (Закон). Розділ 201(s) Закону визначає «харчову добавку» як речовину, для якої обгрунтовано очікується, що вона стане компонентом їжі за передбачених умов використання. Законодавчі винятки передбачені для речовин, які загалом визнані безпечними (GRAS) або $\epsilon$ предметом санкції або схвалення, виданого FDA або Міністерством сільського господарства США до прийняття Поправки до харчових добавок в 1958 р. Харчова продукція, яка містить «небезпечну» харчову добавку сама по собі вважається фальсифікованою відповідно до розділу 402(a)(2)(С) Закону, так званого стандарту «автоматичної фальсифікації». Стандарт фальсифікації 
вимагає, щоб речовина, яка розглядається, була безпечною, тобто щоб вона не додавала до їжі нічого небезпечного та не забруднювала фізично їжу та не надавала неприйнятного смаку чи запаху.

В Україні на сьогодні активне та розумне паковання харчових продуктів (та й будь-яких продуктів загалом) використовують рідко. Особливого регулювання щодо цих видів паковання не встановлено. Закон України «Про основні принципи та вимоги до безпечності та якості харчових продуктів» у ст. 1 містить визначення допоміжних засобів та матеріалів для виробництва та обігу, під яким розуміються матеріали або речовини, включаючи обладнання та інвентар, одиниці упаковки (контейнери), які контактують 3 харчовими продуктами і таким чином впливати на їх безпечність. Ця ж стаття відносить до непридатних («едалтерованих») харчових продуктів такі, що знаходяться у контейнері або упаковці, який частково або повністю складається з отруйних або шкідливих речовин (речовини), що може зробити харчовий продукт небезпечним для здоров'я людини. при цьому одиницею упаковки (контейнером) вважається будь-яка упаковка, включаючи обгортку, незалежно від матеріалу та форми, яка частково або повністю покриває харчовий продукт, для його постачання як окремої одиниці (контейнер може містити кілька упаковок) [12].

При цьому необхідно відзначити, що у вказаному Законі не міститься поняття матеріалів і предметів, які активно контактують 3 продуктами харчування, під якими у Регламенті (СС) 1935/2004 розуміють матеріали і вироби, які призначені для подовження терміну зберігання, захисту, чи покращення якості упакованого продукту; а також поняття «контактуючі 3 харчовими продуктами матеріали і вироби, що мають спеціальні функції», які відповідно до вказаного Регламенту розуміють як «матеріали і вироби, які мають здатність відстежувати якість упакованої їжі чи стан навколишнього середовища» (ст. 2). Частина 2 статті 27 вказаного Закону у пп. 4, 5 забороняє використання допоміжних засобів і матеріалів для виробництва і обігу, які недозволені для прямого контакту 3 харчовими продуктами, а також використання допоміжних засобів і матеріалів для виробництва і обігу, які за своєю природою та складом можуть передавати забруднюючі речовини харчовим продуктам [12]. Необхідно зазначити, що ст. 3 Регламенту (СС) 1935/2004 встановлює більшу кількість заборон, до яких, крім того, належать наступні: процес виготовлення матеріалів i виробів, які призначені для безпосереднього контакту 3 харчовими продуктами, повинен відбуватися 
відповідно до встановлених стандартів виробничої практики, щоб при використання їх складові не потрапляли до харчового продукту у кількості, яка може: бути шкідливою для здоров'я людини; спричинити недопустимі зміни в складі продукту харчування; погіршити його органолептичні якості. Крім того, вартість активного та розумного паковання обмежує його комерційне використання. Більшість активних або розумних систем додають вартості упаковці, тому переваги, забезпечені використанням зазначених технологій, повинні переважувати додаткові витрати, пов'язані з їхнью реалізацією. До того ж, системи повинні бути не тільки безпечним, а й надійними та ефективними. Це вимагає перевірки роботи систем для забезпечення достовірної інформації, що не вводитиме в оману споживача.

Висновки. Активні та розумні системи - це справді інноваційний вид паковання, який розширює можливості упаковки харчових продуктів з погляду безпечності, якості та зручності. Багато активних та розумних концепцій упаковки стали комерційно доступними у розвинутих країнах світу. Наразі перспективним напрямком удосконалення активних систем є використання нанотехнологій, які дозволять включати нові сполуки, такі як антимікробні засоби та поглиначі газу в пакувальні плівки. Розвиток електронних пристроїв, які не потребують значних грошових затрат, також допоможе стимулювати поширення використання активного та розумного паковання. Оскільки, суспільство прогресує, споживач стає більш вибагливим, тому інноваційне паковання, яке покращує якість i безпечність продукту, а також є зручним i зрозумілим у використанні, неодмінно здобуде попит на ринку, i, можливо, у майбутньому повністю замінить традиційне паковання.

Для розвитку галузі активного та розумного паковання в Україні необхідно здобути довіру споживачів до нових технологій, ширше ознайомити ïx 3 перевагами активних i розумних систем, а також розробити чітке законодавство щодо контролю якості та безпечності цих систем.

\section{Список використаних джерел}

1. Dirk Schaefer, Wai M.Cheung (2018). Smart Packaging: Opportunities and Challenges. Procedia CIRP. Volume 27. Pp. 1022-1027. URL: https://doi.org/10.1016/j.procir.2018.03.240

2. De Jong A. R., Boumans H., Slaghek T., Van Veen J., Rijk R., Van M.(2005). Zandvoort Active and intelligent packaging for food: Is it the future? Food Additives \& Contaminants. Volume 22. Issue 10. P. 975-977. URL: https://doi.org/10.1080/02652030500336254. 
3. Muhammad Sohaila, Da-Wen Suna, Zhiwei Zhu (2018). Recent developments in intelligent packaging for enhancing food quality and safety. Critical Reviews in Food Science and Nutrition. Volume 58. Issue 15. URL: https://doi.org/10.1080/10408398.2018.1449731.

4.. Selçuk Yildirim, Bettina Röcker, Marit Kvalvåg Pettersen, Julie Nilsen-Nygaard, Zehra Ayhan, Ramune Rutkaite, Tanja Radusin, Patrycja Suminska, Begonya Marcos, Véronique Coma (2017). Active Packaging Applications for Food Comprehensive Reviews in Food Science and Food Safety. URL: https://doi.org/10.1111/1541-4337.12322.

5. Matthew Deas Wilson, ,Roger A Stanley,Alieta Eyles \&Tom Ross (2019). Innovative processes and technologies for modified atmosphere packaging of fresh and fresh-cut fruits and vegetables. Critical Reviews in Food Science and Nutrition. Volume 59, 2019. Issue 3. URL: https://doi.org/10.1080/10408398.2017.1375892.

6. Ayhan Z. (2013). Potential applications of nanomaterials in food packaging and interactions of nanomaterials with food. Ecosustainable polymer nanomaterials for food packaging: Innovative solutions, characterization needs, safety and environmental issues. Boca Raton, Florida, U.S.A.: CRC Press. p 243- 79.

7. Azlin-Hasim S, Cruz-Romero MC, Morris MA, Padmanabhan SC, Cummins E, Kerry JP. (2016). The potential application of antimicrobial silver polyvinyl chloride nanocomposite films to extend the shelf-life of chicken breast fillets. Food Bioprocess Tech 9(10): 1661- 73. URL: https://doi.org/10.1007/s11947-016-1745-7.

8. Donatella Restuccia, U. Gianfranco Spizzirri, Ortensia I. Parisi, Giuseppe Cirillo, Manuela Curcio, Francesca Iemma, Francesco Puoci, Giuliana Vinci, Nevio Picci (2010). New EU regulation aspects and global market of active and intelligent packaging for food industry applications. Food Control. Volume 21. Issue 11. P. 1425-1435. URL: https://doi.org/10.1016/j.foodcont.2010.04.028.

9. Regulation (EC) №1935/2004 of the European parlament and of the council. URL:https://eurlex.europa.eu/LexUriServ/LexUriServ.do?uri=OJ:L:2004:338:0004:0017:en.

10. Commission regulation (EC) №450/2009. URL: https://eurlex.europa.eu/LexUriServ/LexUriServ.do?uri=OJ:L:2009:135:0003:0011:EN:PDF.

11 Regulation (EC) №1333/2008 of the European parlament and of the council. URL: https://eurlex.europa.eu/legal-content/EN/TXT/PDF/?uri=CELEX:32008R1333\&from=EN.

12. Про основні принципи та вимоги до безпечності та якості харчових продуктів : Закон України 771/97-BP. [On the basic principles and requirements for food safety and quality: Law of Ukraine] URL: https://zakon.rada.gov.ua/laws/show/771/97-\%D0\%B2\%D1\%80\#Text

Purpose. The aim of the article is to consider the main types of active and intelligent food packaging, to analyze their advantages and disadvantages, in particular, their impact on product quality and safety and informative function of the packaging, to review the main technologies that can be used in active and intelligent systems, as well as, to analyze the existing legislation regulating the use of active and intelligent packaging, and to identify the main obstacles that limit the use of innovative types of packaging in Ukraine.

Methodology. Methods of theoretical search, system approach and logical generalization are used. 
Results. The article presents the classification of active and intelligent packaging, as well as briefly discusses the main technologies used in intelligent and active systems. Examples of active and intelligent packaging for different types of food products are given, the advantages of its use for food packaging are substantiated. The problem of safety of active and intelligent packaging and regulation of its use on the example of EU, US and Ukrainian legislation is analyzed. The issues that impede the widespread use of innovative packaging technologies in Ukraine and the world, as well as prospects for their further development have been identified.

Scientific novelty. Today, active and smart packaging is almost not available to Ukrainian consumers. So far, the obstacles and prospects for the development of these types of packaging in Ukraine have not been fully considered and structured.

Practical significance. Society is becoming increasingly complex and innovative packaging is the result of consumers' demand for packaging that is more advanced and creative than what is currently offered. Active and smart packaging is the result of innovative thinking in packaging. It can improve the quality and safety of food, as well as provide consumers with up-to-date information about the state of the product, which changes over time. The spread of new packaging technologies is a necessary stage in the development of trade, which is able to meet the increasingly complex requirements of the consumer, reduce food waste and make packaging better, safer and more convenient.

Key words: packaging technologies, active packaging, intelligent packaging, food products, quality, safety.

Стаття рекомендована до друку доктором технічних наук, професором Байдаковою Л.І. Дата надходженняв редакцію 05.01.2021 p. 